\title{
The Dutch residency educational climate test: construct and concurrent validation in Spanish language
}

\author{
Luis Carlos Domínguez¹, Milou E.W.M. Silkens'², Alvaro Sanabria ${ }^{3}$ \\ ${ }^{1}$ Department of Surgery, Universidad de la Sabana, Bogotá, Colombia \\ ${ }^{2}$ Professional Performance and Compassionate Care research group, Department of Medical Psychology, Amsterdam UMC, \\ Amsterdam, the Netherlands \\ ${ }^{3}$ Department of Surgery, Universidad de Antioquia, Medellín, Colombia
}

Correspondence: Luis Carlos Dominguez, Department of Surgery, Universidad de la Sabana, Bogotá, Colombia

E-mail: carlosdot@unisabana.edu.co

Accepted: June 21, 2019

\begin{abstract}
Objectives: To translate the 35-item version of the Dutch Residency Educational Climate Test (D-RECT), and assess its reliability, construct validity and concurrent validity in the Spanish language.

Methods: For this validation study, the D-RECT was translated using international recommendations. A total of 220 paper-based resident evaluations covering two Colombian universities were cross-sectionally collected in 2015. A Confirmatory Factor Analysis (CFA) was used to assess the internal validity of the instrument using the Comparative fit index (CFI), Tucker-Lewis index (TLI), Standardized root mean square residual (SRMSR), and Root mean square error of approximation (RMSA). Cronbach's a was used to assess reliability. The concurrent validity was investigated through Pearson correlations with the Spanish version of the
\end{abstract}

Postgraduate Hospital Educational Environment Measure (PHEEM).

Results: The original 9-factor structure showed an appropriate fit for the Spanish version of the instrument $(\mathrm{CFI}=0.84$, $\mathrm{TLI}=0.82$, SRMSR $=0.06$, and RMSA $=0.06$ ). The reliability coefficients were satisfactory $(>0.70)$. The mean total scores of the D-RECT and the PHEEM showed a significant correlation $(\mathrm{r}=0.7, \mathrm{p}<0.01)$.

Conclusions: This study confirms the validity and reliability of the Spanish version of the Dutch Residency Educational Climate Test, indicating that the instrument is suitable for the evaluation of departments' learning climate in the Spanish context. Future research is needed to confirm these findings in other Spanish speaking countries.

Keywords: Postgraduate medical education, learning climate, psychometrics, D-RECT, Colombia

\section{Introduction}

Evaluating the learning climate in postgraduate medical education (PGME) is a cornerstone to assure the quality of residency training as well as of patient care provided by residents. The learning climate can be defined as residents' perceptions of both formal and informal characteristics of education. ${ }^{1,2}$ More specifically, the learning climate refers to perceptions about common practices and procedures at the department ${ }^{3}$ as well as the quality of relationships between residents and their clinical teachers, supervisors, and the institution. ${ }^{4}$ Multiple instruments have been developed to evaluate the learning climate in residency training, which exhibit variable grades of validity, reliability, and acceptability. ${ }^{2,5-7}$
Despite the increased attention for learning climates in PGME worldwide and the number of instruments that developed as a result of this attention, the availability of such instruments in the Spanish language is limited. This lack of instruments sets boundaries to the continuous improvement of the learning climate in Spanish speaking countries, thereby impacting on academic outcomes that are routinely evaluated in other contexts (e.g., academic performance, self-directed learning, residents' training experience and wellbeing). $4,6,8,9$

One of the most commonly used instruments to evaluate learning climates in PGME worldwide is the Postgraduate 
Hospital Educational Environment Measure (PHEEM). The PHEEM was developed through a grounded theory approach involving focus groups and a Delphi method. ${ }^{2}$ A recent systematic review examined the adoption and use of PHEEM in different medical contexts and highlighted its reliability and internal consistency. ${ }^{10}$ For Spanish speaking countries; the PHEEM is the most accepted instrument for the evaluation of the learning climate in PGME. ${ }^{10-12}$ Another instrument, the Ambulatory Care Learning Education Environment Measure (ACLEEM), is also available in Spanish language but it has received less attention than PHEEM. ${ }^{13}$ ACLEEM is limited to ambulatory settings and involves the evaluation of residents' support, clinical teaching, and clinical skills. As such, it has been recommended that alternative instruments should be developed and administered in the Spanish-speaking context to provide a more holistic and accurate picture of the educational environment. ${ }^{11,14}$

As an alternative to the PHEEM, the Dutch Residency Educational Climate Test (D-RECT) was developed in the Netherlands to assess learning climates in PGME. ${ }^{15}$ As opposed to other instruments at the time, the initial 75-item version of the D-RECT was constructed in Dutch and based on a theoretical framework drawn from literature research, qualitative research and a Delphi method. ${ }^{15}$ The instrument was reduced to 50 items in an initial validation study including exploratory, confirmatory, and generalizability analysis, showing appropriate validity and reliability at the resident level. The D-RECT was subsequently translated in English and findings were explored in other settings. ${ }^{16-18}$ For some settings the psychometric properties of 50-item D-RECT were controversial, requesting a need for further revision. ${ }^{19}$ Simultaneously, the instrument was critically revised in the Netherlands in order to guarantee the validity and reliability on the intended unit of analysis (the clinical departments providing PGME).$^{20}$ This revision showed that the learning climate could be evaluated on both the resident and the department level using a 35-item questionnaire consisting of nine dimensions. This updated version of the D-RECT offered advantages over other instruments aimed at evaluating learning climates in PGME, such as a solid theoretical underpinning, strong psychometric properties due to an extensive validation process, and applicability to the department level. ${ }^{20}$ Although the 35 -item D-RECT performed well in the Dutch context, testing its psychometric properties in international contexts and other languages were considered an important knowledge gap. ${ }^{20} \mathrm{Up}$ to date, the 35 -item D-RECT has only been tested and adjusted to the Filipino context, showing psychometric validity after minor modifications. ${ }^{21}$ This means that there is a need for additional research to further assess the psychometric properties of the 35-items DRECT in other non-western contexts.

Considering the increasing popularity of the D-RECT, its recent update and the challenges brought forward by the limited number of learning climate instruments in Spanish, this study aimed to translate the 35 -item D-RECT into the Spanish language and assess its construct and concurrent validity and reliability. This study aimed to provide psychometric evidence for the D-RECT in the Spanish-speaking context to extend the existing toolkit of instruments available for the evaluation of the learning climate in PGME. This study poses the following research question: what are the construct and concurrent validity, and the reliability of the 35 -item DRECT in the Spanish language?

\section{Methods}

\section{Study design and participants}

The present study was designed as a cross-sectional study that was conducted in two universities in Colombia (one public and one private). In these universities, residents complete full-time training during two to five years (depending on specialty) and subsequently apply to sub-specialties (usually taking two more years). Residents pay a fee to the university but usually do not receive a salary from hospitals, though a few residents receive a semi-annual governmental scholarship. The national directive of duty hours is 66 hours per week.

For the current study, residents from both universities were invited to complete the D-RECT questionnaire. A total of 245 residents from 17 different surgical and non-surgical specialties completed the D-RECT questionnaire. Twentyfive questionnaires were removed from further analysis due to missing data, leaving $220 \mathrm{D}$-RECT evaluations for further analysis. The mean age of the respondents was 28.8 years (SD $=2.8$ ), of which 120 respondents were female (54.5\%), and 97 were male $(44.1 \%)$. The distribution of respondents according to the postgraduate year of residency (PG-Y) was: PG-Y1 (46.8\%), PG-Y2 (26.8\%), PG-Y3 (19.1\%) and PG-Y4 (6.8\%). Table 1 provides further details on the study population.

\section{Instruments}

We used the D-RECT as well as PHEEM to evaluate the learning climate in PGME. The most recent version of the DRECT questionnaire is validated in the Netherlands and consists of 35 items covering nine domains (educational atmosphere, teamwork, the role of specialty tutor, coaching and assessment, formal education, resident peer collaboration, work is adapted to residents' competence, accessibility of supervisors and patient sign-out). 20 Respondents could rate items using a 5-point Likert scale ( 1 = totally disagree, $2=$ disagree, 3 = neutral, $4=$ agree, $5=$ totally agree $).{ }^{20}$

The validated Spanish PHEEM questionnaire consists of 40 items covering 5 domains (perceptions of teaching and learning, teaching and social support/counselling opportunities, fairness of the program, autonomy and accommodation and catering facilities). ${ }^{10}$ Respondents could rate items using a 5 -point Likert scale $(1=$ totally disagree, $2=$ disagree, $3=$ neutral, $4=$ agree, $5=$ totally agree) ${ }^{10,12,22}$ 
An in-depth description of the domains as well as an overview of the conceptual overlap between the two instruments is presented in Appendix A1.

Table 1. Characteristics of the study population $(\mathrm{N}=220)$

\begin{tabular}{|c|c|}
\hline Characteristics & Study sample \\
\hline Age (years), mean (SD)* & $28.8(2.8)$ \\
\hline Gender & n (\%) \\
\hline Male & $97(44.1)$ \\
\hline Female & $120(54.5)$ \\
\hline Missing & $3(1.4)$ \\
\hline \multicolumn{2}{|l|}{ Year of training } \\
\hline 1 & $103(46.8)$ \\
\hline 2 & 59 (26.8) \\
\hline 3 & $42(19.1)$ \\
\hline 4 & $15(6.8)$ \\
\hline Missing & $1(0.5)$ \\
\hline \multicolumn{2}{|l|}{ Specialty } \\
\hline Cardiovascular Electrophysiology & $2(0.9)$ \\
\hline Rheumatology & $2(0.9)$ \\
\hline Critical care medicine (paediatrics) & $2(0.9)$ \\
\hline Critical care medicine (adult) & $14(6.4)$ \\
\hline Pulmonary care & $4(1.8)$ \\
\hline Internal medicine & $34(15.5)$ \\
\hline Family medicine & 39 (17.7) \\
\hline Radiology & $10(4.5)$ \\
\hline General surgery & $14(6.4)$ \\
\hline Anaesthesiology & $17(7.7)$ \\
\hline Physical and rehabilitation medicine & $13(5.9)$ \\
\hline Ophthalmology & $4(1.8)$ \\
\hline Gynaecology & $13(5.9)$ \\
\hline Neurology & $4(1.8)$ \\
\hline Clinical pharmacology & $12(5.5)$ \\
\hline Paediatrics & $30(13.6)$ \\
\hline Orthopaedics & $6(2.7)$ \\
\hline
\end{tabular}

*SD = Standard Deviation

\section{Translation of the D-RECT into Spanish}

We contacted one of the authors of the original 35-item DRECT to get authorization for using the questionnaire. We translated the English items into Spanish following the recommendations of the International Quality of Life Assessment project (IQOLA), which were previously applied to translate the SF-36 Health Survey from English into other languages. ${ }^{23}$ Initially, two natively Spanish speaking researchers performed two independent forward translations from English into Spanish (LD, AS). Translations were compared and unified into a single version. Once completed, two certified bilingual translators performed two independent backward translations of from Spanish into English and subsequently, a third certified translator unified these translations into one version. Hereafter, one of the authors of the original 35-item D-RECT compared the resulting backward translation with the original version (MS). To conclude, the main researchers (LD, MS, AS) organized various meetings to clarify any discrepancies and to generate the final Spanish DRECT. The researchers then conducted a pilot with twenty residents from different specialties in the Faculty of Medicine (Universidad de la Sabana, Colombia) to test the Spanish DRECT and to appraise whether they found any difficulty, upsetting, or confusing items. Simultaneously the authors assess the process of response. The Spanish version of the D-RECT is available in Appendix A2.

\section{Data collection}

We prepared a paper-based questionnaire for data collection, which consisted of the Spanish D-RECT, as well as the Spanish PHEEM questionnaire. ${ }^{10}$ We collected data during the weekly meetings of the postgraduate programs in both Colombian universities, during which residents were asked to complete the questionnaire individually. The first author coordinated the admission of the questionnaire during these meetings and was also responsible for the collection of completed questionnaires. Also, the purpose of the study, voluntariness to participate, anonymity, confidentiality and further management of information was explained to residents during these meetings. The data were collected from October to December 2015. Once completed, the first author coordinated the transcription and organization of data in order to guarantee the quality and integrity of information. The ethical approval for the present study was provided by the Commission of Medical Education (Facultad de Medicina, Universidad de la Sabana, Colombia).

Table 2. Fit indices for the 9-factor structure of the D-RECT in Spanish and the D-RECT in Dutch

\begin{tabular}{lccc}
\hline Fit indices & $\begin{array}{c}\text { Spanish } \\
\text { D-RECT } \\
\text { (resident level) }\end{array}$ & $\begin{array}{c}\text { Dutch D-RECT } \\
\text { (resident level) }\end{array}$ & $\begin{array}{c}\text { Dutch D-RECT } \\
\text { (department } \\
\text { level) }\end{array}$ \\
\hline CFI & 0.84 & 0.92 & 0.89 \\
TLI & 0.82 & 0.91 & 0.88 \\
SRMR & 0.06 & 0.04 & 0.06 \\
RMSEA & 0.06 & 0.04 & 0.06 \\
\hline
\end{tabular}

\section{Data analysis}

Frequencies and descriptive statistics were performed to gain insight in relevant study sample characteristics. Resident evaluations that exceeded 50\% missing data for the D-RECT or PHEEM were excluded. For both the D-RECT and the PHEEM, subscale scores were computed by averaging item scores. We allowed one item per subscale to have missing data. Similarly, mean total scores were calculated for both instruments. Pearson correlation was used to examine the correlation between the domains as well as mean total scores of both instruments. For the D-RECT data, remaining missing data were imputed using expectation maximization (EM). The internal consistency of the 9-factor structure was assessed by calculating Cronbach's $\alpha$. A Cronbach's a exceeding 0.70 was considered satisfactory. ${ }^{24}$ Corrected item-total correlations were computed to examine the homogeneity of each subscale. An item-total correlation above 0.40 was considered satisfactorily. ${ }^{25}$ Subscales scored satisfactorily on overlap when inter-scale correlations remained under 0.70 .

To assess the fit of the 9-factor structure for the Spanish version of the D-RECT, a confirmatory factor analysis (CFA) was performed. Robust maximum likelihood was used to estimate the CFA model. The fit of the model was assessed by combining the following fit indices: the comparative fit index (CFI), the Tucker-Lewis index (TLI), the standardized 
Table 3. Pearson correlations for PHEEM and D-RECT domains

\begin{tabular}{|c|c|c|c|c|c|}
\hline D-RECT / PHEEM Domains & $\begin{array}{l}\text { Perceptions of } \\
\text { teaching and } \\
\text { learning }\end{array}$ & $\begin{array}{l}\text { Teaching and social } \\
\text { support/counselling } \\
\text { opportunities }\end{array}$ & $\begin{array}{c}\text { Fairness of the } \\
\text { program }\end{array}$ & Autonomy & $\begin{array}{l}\text { Accommodation and } \\
\text { catering facilities }\end{array}$ \\
\hline Coaching and assessment & $0.61^{* *}$ & $0.51^{* *}$ & $0.24^{* *}$ & $0.68^{* *}$ & $0.25^{\star *}$ \\
\hline Accessibility of supervisors & $0.52^{\star *}$ & $0.41^{* *}$ & $0.30^{* *}$ & $0.55^{\star *}$ & $0.34^{* *}$ \\
\hline Role of specialty tutor & $0.61^{* *}$ & $0.37^{\star *}$ & $0.29^{* *}$ & $0.57^{* *}$ & $0.29^{\star *}$ \\
\hline Teamwork & $0.43^{\star *}$ & $0.34^{* *}$ & $0.27^{* *}$ & $0.40^{* *}$ & $0.36^{\star *}$ \\
\hline Resident peer collaboration & $0.24^{\star *}$ & $0.15^{\star}$ & $0.13^{*}$ & $0.28^{* *}$ & 0.13 \\
\hline Educational atmosphere & $0.63^{* *}$ & $0.51^{* *}$ & $0.35^{\star *}$ & $0.50^{\star *}$ & $0.37^{\star *}$ \\
\hline Formal education & $0.63^{* *}$ & $0.53^{* *}$ & $0.35^{* *}$ & $0.62^{* *}$ & $0.34^{* *}$ \\
\hline Work is adapted to residents' competence & $0.47^{\star \star}$ & $0.36^{\star *}$ & $0.27^{\star *}$ & $0.45^{\star *}$ & $0.24^{* *}$ \\
\hline Patient sign-out & $0.50^{* \star}$ & $0.38^{* *}$ & $0.18^{* *}$ & $0.54^{* *}$ & $0.17^{*}$ \\
\hline
\end{tabular}

${ }^{*}<0.05 ;{ }^{* *}<0.01$

root mean square residual (SRMR) and the root mean square error of approximation (RMSEA). We used pre-determined cut-off values to assess the fit (CFI and TLI $>0.95$ for good fit and $>0.90$ for acceptable fit; SRMR $<0.08$ for good fit and $<0.12$ for acceptable fit and RMSEA $<0.06$ for good fit and $<0.10$ for acceptable fit). ${ }^{26}$ The Lavaan package in R statistical software version 3.3.1 was used to perform the CFA. ${ }^{27}$ All other analyses were performed in SPSS version 23 (IBM Corp. 2015).

\section{Results}

\section{Reliability and construct validity of the D-RECT}

Cronbach's $\alpha$ for the nine subscales of the D-RECT were as follows: 0.78 (subscale 'work is adapted to residents' competence'), 0.84 (subscale 'teamwork', 'resident peer collaboration', and 'formal education'), 0.86 (subscale 'educational atmosphere' and 'accessibility of supervisors'), and 0.88 (subscale 'role of specialty tutor', 'coaching and assessment', and 'patient sign-out'). Corrected item-total correlations ranged from 0.45 (Item "It is possible to do follow up with patients") to 0.82 (Item "Differences of opinion are not such that they have a negative impact on the work climate") (Appendix A2). Inter-scale correlations ranged from 0.21 (subscale 'patient sign-out' versus subscale 'resident peer collaboration') to 0.76 (subscale 'coaching and assessment' versus 'subscale role specialty tutor') (Appendix A3). Table 2 shows the results for the CFA and the original fit indices for the Dutch D-RECT. Appendix A2 shows the standardized and unstandardized coefficients and the corresponding standard errors for observed and latent variables.

\section{Concurrent validity of the D-RECT}

Mean scores for the subscales of the D-RECT varied from 3.6 (subscale 'patient sign-out'; $\mathrm{SD}=0.9$ ) to 4.3 (subscale 'resident peer collaboration'; $S D=0.7)$. Detailed summary statistics for the subscales of the D-RECT are provided in Appendix A2. The D-RECT had an overall mean score of 3.9 (SD = 0.6). Mean scores for the subscales of the PHEEM varied from 3.3 (subscale 'teaching and social support/counselling opportunities'; $\mathrm{SD}=0.6$ ) to 4.0 (subscale 'teaching and Int J Med Educ. 2019;10:138-148 learning'; $\mathrm{SD}=0.6)$. The PHEEM had an overall mean score of 3.8 $(\mathrm{SD}=0.5)$. Pearson correlation showed all PHEEM and D-RECT domains were significantly correlated, except for the PHEEM domain 'perceptions of teaching' and the DRECT domain 'resident peer collaboration' (Table 3). A significant correlation between the overall mean scores of the 35 -item D-RECT and the PHEEM ( $\mathrm{r}=0.7, \mathrm{p}=<0.01)$.

\section{Discussion}

This study translated and validated the revisited 35-item DRECT questionnaire in the Spanish language by using standard recommendations. ${ }^{23} \mathrm{We}$ found that this instrument can evaluate the learning climate in postgraduate training in Spanish with adequate reliability and construct validity. The results obtained from the correlation analysis showed a high level of confidence that the Spanish D-RECT measures a similar construct to the Spanish PHEEM, namely the learning climate in postgraduate training.

The core structure used in the CFA resembles the structure reported by Silkens and colleagues. ${ }^{20}$ accounting for nine learning climate domains: educational atmosphere, teamwork, the role of specialty tutor, coaching and assessment, formal education, resident peer collaboration, work is adapted to residents' competence, accessibility of supervisors and patient sign-out. When investigating the fit indices, the SRMR showed a very good fit and the RMSEA showed good fit, indicating the a priori model fits well to the data. The assumption that the 9-factor structure works well in the Spanish context is further supported by satisfactorily item-total correlations, pointing out that every item contributed to the overall learning climate construct. However, both the CFI and TLI fit indices were $<0.9$, showing a limited improvement of the tested model to a restricted model. This might suggest that the proposed structure is not the most optimal in the Spanish context. The inter-scale correlations, though mainly very satisfactorily, did show a high correlation between the subscales 'role of specialty tutor' and 'coaching and assessment'. The overlap between these subscales could plead for a merge or textual alteration of the two scales. Overall, the Spanish 35-item D-RECT did satisfactorily meet most of the 
criteria posed. Especially since reliability coefficients show outstanding performance on all nine subscales, we believe the instrument in its current form is usable in the Spanish context according to previous recommendations. ${ }^{28}$

With regards to the concurrent validity, when comparing the Spanish D-RECT to the Spanish version of the PHEEM, we observed a high correlation between domain scores and total mean scores of both instruments. Only a few studies focused on the concurrent validity of the PHEEM. In a preliminary study, the Job Evaluation Survey Tool (JEST) developed in the UK was correlated against PHEEM, showing high Spearman correlation coefficients. ${ }^{29}$ No previous studies have assessed the concurrent validity of D-RECT, implying the contribution of our study valuable to the validity evidence of the D-RECT. In particular, we found that the positive correlations between the two instruments suggest that the outcomes of instruments are related. Since PHEEM is currently the most often used instrument to assess the learning climate in the Spanish language, a high correlation is promising for the D-RECT, indicating both the PHEEM and D-RECT are multidimensional instruments measuring a similar construct. Nonetheless, there are important differences in the tools' domains, indicating that both tools are measuring the same construct from different angles. While PHEEM evaluates perceptions of the domains 'teaching and learning', 'social support and counselling', 'fairness and inappropriate tasks', 'autonomy', and 'organization and catering, ,, 10 the D-RECT evaluates perceptions of domains such as 'the educational atmosphere', 'teamwork', 'role of specialty tutor' and 'coaching and assessment'. ${ }^{15,20}$ Several domains in both instruments do address similar overarching constructs such as 'supervision', 'social support' and 'interaction between professionals at the departments'. However, both instruments address unique domains as well (Table 1). These differences should be taken into account where particular measurements of the learning climate are anticipated, as well as for purposes of comparison between different contexts.

\section{Strengths and limitations of the study}

The present study adds support for the 35-item D-RECT in a new context, namely the Spanish language. We recruited medical residents from different universities, including public and private institutions, with a wide distribution of specialties that are representative of common conditions in Latin America, guaranteeing the generalizability of the results. Furthermore, we followed a rigorous process of translation following international recommendations and pilot tested the Spanish items in a small group of residents before the start of data collection.

The main limitation of the present study is that the D-RECT was tested in a non-aggregated form, providing information on the resident level only. As these limitations are due to the sample size achieved in the study, researching a wider number of residency programs would support the generalizability of results to the department level. Furthermore, a larger sample could offer information about differences between programs: information the present study is not able to provide. Another limitation of the present study is the absence of exploratory factor analysis. Following the example of the original validation of the D-RECT, we preferred splitting the sample and used part of the sample for exploratory factor analysis and the other part of the sample to confirm the identified structure with a CFA. However, as the original validation procedure of the D-RECT already identified a solid structure by using a CFA and as the content of the D-RECT was applicable in the Colombian context without alterations, we identified a CFA as the preferred method to assess the psychometric properties of the Spanish instrument. Finally, although the results of the present study provide a Spanish version of the D-RECT that is valid and reliable, other Spanish speaking countries should thoroughly assess the instrument to decide whether the instrument applies to other Spanish contexts in terms of content.

\section{Implications for practice and future research}

This study contributes to the lack of instruments for evaluating the learning climate in the Spanish language. The 35-item D-RECT can now be added to the toolbox of valid learning climate instruments in residency training. The validation of this instrument offers a standardized and objective method to evaluate the learning climate in Spanish language countries and to compare its different educational contexts, for example, compare differences in performance between specialties. Furthermore, it provides a reliable tool to evaluate improvement after curricular and educational changes are done. ${ }^{3,30-32}$ Ultimately, the instrument can be used for research into the effect of the learning climate on patient outcomes and health care system cost-effectiveness. A good instrument to measure the learning climate in residency training offers an opportunity to understand the internal elements of climate and its relationship with patient outcomes. When educators and researchers wish to evaluate the learning climate, it is important that they assess their goals in order to pick the right instrument from the existed toolbox. Whether the PHEEM or the D-RECT is the preferred instrument might depend on the goals of evaluation, and as such, cautiousness is advised for proper selection. Above all, it is important to realize that instruments such as the PHEEM and the D-RECT need continuous attention. Similarly, further studies are needed to establish the concurrent validity of the Spanish versions of D-RECT and PHEEM against, for example, ACLEEM. ${ }^{13}$ The practice is changing all the time, and so should these instruments to adapt to these changes. As we stated above, the D-RECT should be tested in other Spanish speaking countries were conditions for residency training, and wellbeing during training could be affected by different health and educative systems. We call for further research in this area. 


\section{Conclusions}

In conclusion, our study demonstrates that the Spanish version of the 35-item D-RECT is valid, reliable, and a contextually appropriate instrument for the evaluation of the learning climate of postgraduate training in Spanish language contexts. The use of this instrument contributes to the toolkit of available instruments for measurement of learning climate, such as the PHEEM, in order to improve the quality of postgraduate education.

\section{Conflict of Interest}

The authors declare that they have no conflict of interest.

\section{References}

1. Delva MD, Kirby J, Schultz K, Godwin M. Assessing the relationship of learning approaches to workplace climate in clerkship and residency. Acad Med. 2004;79(11):1120-6.

2. Roff S, McAleer S, Skinner A. Development and validation of an instrument to measure the postgraduate clinical learning and teaching educational environment for hospital-based junior doctors in the UK. Med Teach. 2005;27(4):326-31.

3. Lombarts KMJMH, Heineman MJ, Scherpbier AJJA, Arah OA. Effect of the learning climate of residency programs on faculty's teaching performance as evaluated by residents. PLoS One. 2014; 9(1):e86512.

4. Biggs J, Tang C. Teaching for quality learning at university. Maidenhead, UK: Open University Press. 2011.

5. Cassar K. Development of an instrument to measure the surgical operating theatre learning environment as perceived by basic surgical trainees. Med Teach. 2004;26(3):260-4.

6. Miles S, Swift L, Leinster SJ. The Dundee Ready Education Environment Measure (DREEM): a review of its adoption and use. Med Teach. 2012;34(9):e620-34.

7. Holt MC, Roff S. Development and validation of the Anaesthetic Theatre Educational Environment Measure (ATEEM). Med Teach. 2004;26(6):5538.

8. Mitchell R, Jack B, McQuade W. Mapping the cognitive environment of a residency: an exploratory study of a maternal and child health rotation. Teaching and Learning in Medicine. 1999;11(1):6-11.

9. Lases LSS, Arah OA, Busch ORC, Heineman MJ, Lombarts KMJMH. Learning climate positively influences residents' work-related well-being. Adv Heal Sci Educ. 2019;24(2):317-330.

10. Riquelme A, Herrera C, Aranis C, Oporto J, Padilla O. Psychometric analyses and internal consistency of the PHEEM questionnaire to measure the clinical learning environment in the clerkship of a medical school in Chile. Med Teach. 2009;31(6):e221-5.

11. Domínguez LC. Instrumentos para la evaluación del clima de aprendizaje en residencias médicas: síntesis de la evidencia a la luz de las definiciones psicométricas. Educación Médica. 2018;19(Supl.3):335-49.

12. Herrera CA, Olivos T, Román JA, Larraín A, Pizarro M, Solís N, et al. Evaluación del ambiente educacional en programas de especialización médica. Rev Med Chile. 2012;140(12):1554-61.

13. Riquelme A, Padilla O, Herrera C, Olivos T, Román JA, Sarfatis A, et al. Development of ACLEEM questionnaire, an instrument measuring residents' educational environment in postgraduate ambulatory setting. Med Teach.2013;35(1): e861-6.
14. Chan CYW, Sum MY, Lim WS, Chew NWM, Samarasekera DD, Sim K. Adoption and correlates of Postgraduate Hospital Educational Environment Measure (PHEEM) in the evaluation of learning environments - a systematic review. Med Teach. 2016;38(12):1248-55.

15. Boor K, Van Der Vleuten C, Teunissen P, Scherpbier A, Scheele F. Development and analysis of D-RECT, an instrument measuring residents' learning climate. Med Teach. 2011;33(10):820-7.

16. Bennett D, Dornan T, Bergin C, Horgan M. Postgraduate training in Ireland: expectations and experience. Irish J Med Sci. 2014;183(4):611-20.

17. Piek J, Bossart M, Boor K, Halaska M, Haidopoulos D, Zapardiel I, et al. The workplace educational climate in gynecological oncology fellowships across Europe: the impact of accreditation. Int J Gynecol Cancer. 2015;25(1):180-90.

18. Pinnock R, Welch P, Taylor-Evans H, Quirk F. Using the DRECT to assess the intern learning environment in Australia. Med Teach. 2013;35(8):699.

19. Iblher P, Zupanic M, Ostermann T. The Questionnaire D-RECT German: Adaptation and testtheoretical properties of an instrument for evaluation of the learning climate in medical specialist training. GMS Z Med Ausbild. 2015;32(5):Doc55.

20. Silkens MEWM, Smirnova A, Stalmeijer RE, Arah OA, Scherpbier AJJA, Van Der Vleuten CPM, et al. Revisiting the D-RECT tool: validation of an instrument measuring residents' learning climate perceptions. Med Teach. 2015;38(5):1-6.

21. Pacifico JL, van der Vleuten CPM, Muijtjens AMM, Sana EA, Heeneman S. Cross-validation of a learning climate instrument in a non-western postgraduate clinical environment. BMC Med Educ. 2018;18(1):22.

22. Llera J, Durante E. Correlation between the educational environment and burn-out syndrome in residency programs at a university hospital. Arch Argent Pediatr. 2014;112(1):6-11.

23. Bullinger M, Alonso J, Apolone G, Leplège A, Sullivan M, Wood-Dauphinee S, et al. Translating health status questionnaires and evaluating their quality: the IQOLA project approach. International Quality of Life Assessment. J Clin Epidemiol. 1998;51(11):913-23.

24. Cronbach LJ, Warrington WG. Time-limit tests: estimating their reliability and degree of speeding. Psychometrika. 1951;16(2):167-88.

25. Arah OA, Hoekstra JBL, Bos AP, Lombarts KMJMH. New tools for systematic evaluation of teaching qualities of medical faculty: results of an ongoing multi-center survey. PLoS One. 2011;6(10):e25983.

26. Brown TA. Confirmatory factor analysis for applied research. Confirmatory factor analysis for applied research. New York: The Guilford Press. 2006;475.

27. Rosseel Y. Lavaan: an R Package for structural equation modeling. J Stat Softw. 2012;48(2):1-36.

28. Nunnally JC, Bernstein IH. Psychometric theory. New York: McGrawHill. 1994.

29. Wall D, Goodyear H, Singh B, Whitehouse A, Hughes E, Howes J. A new tool to evaluate postgraduate training posts: the Job Evaluation Survey Tool (JEST). BMC Med Educ. 2014;14(1):210.

30. Silkens MEWM, Arah OA, Scherpbier AJJA, Heineman MJ, Lombarts KMJMH. Focus on quality: investigating residents' learning climate perceptions. PLoS One. 2016;11(1):e0147108.

31. Silkens MEWM, Arah OA, Wagner C, Scherpbier AJJA, Heineman MJ, Lombarts KMJMH. The relationship between the learning and patient safety climates of clinical departments and residents' patient safety behaviors. Acad Med. 2018;93(9):1374-80.

32. Silkens MEWM, Slootweg IA, Scherpbier AJJA, Heineman MJ, Lombarts KMJMH. Hospital-wide education committees and high-quality residency training: a qualitative study. Perspect Med Educ. 2017;6(6):396-404. 


\section{Appendix A1}

Content of domains for the PHEEM and D-RECT as well as conceptual overlap

\begin{tabular}{|c|c|c|c|c|}
\hline \multirow{2}{*}{ Overarching themes } & \multicolumn{2}{|r|}{ PHEEM } & \multicolumn{2}{|r|}{ D-RECT } \\
\hline & Domains & Content of Items & Domains & Content of Items \\
\hline \multirow[t]{2}{*}{ Supervision } & $\begin{array}{l}\text { Perceptions of teach- } \\
\text { ing and learning }\end{array}$ & $\begin{array}{l}\text { Arrangement of learning op- } \\
\text { portunities and aspects of su- } \\
\text { pervision during learning op- } \\
\text { portunities and providing } \\
\text { patient care }\end{array}$ & $\begin{array}{l}\text { Coaching and } \\
\text { assessment }\end{array}$ & $\begin{array}{l}\text { Aspects of supervision and } \\
\text { feedback behaviour of } \\
\text { supervisors }\end{array}$ \\
\hline & & & $\begin{array}{l}\text { Accessibility of } \\
\text { supervisors }\end{array}$ & $\begin{array}{l}\text { The availability of supervisors } \\
\text { when residents are in need }\end{array}$ \\
\hline \multirow[t]{3}{*}{$\begin{array}{l}\text { Social support and } \\
\text { overall guidance }\end{array}$} & $\begin{array}{l}\text { Teaching and social } \\
\text { support/ } \\
\text { counselling opportu- } \\
\text { nities }\end{array}$ & $\begin{array}{l}\text { Available time, social support, } \\
\text { and resources for residents to } \\
\text { participate in educational and } \\
\text { career activities as well as } \\
\text { patient care }\end{array}$ & Role of specialty tutor & $\begin{array}{l}\text { Involvement of the specialty } \\
\text { tutor in the learning trajectory } \\
\text { of the resident }\end{array}$ \\
\hline & & & Teamwork & $\begin{array}{l}\text { Collaborating relations with } \\
\text { other healthcare staff at the } \\
\text { department }\end{array}$ \\
\hline & & & $\begin{array}{l}\text { Resident peer } \\
\text { collaboration }\end{array}$ & $\begin{array}{l}\text { Collaborating relations } \\
\text { amongst residents }\end{array}$ \\
\hline Appropriate interaction & $\begin{array}{l}\text { Fairness of the } \\
\text { program }\end{array}$ & $\begin{array}{l}\text { The occurrence of inappropri- } \\
\text { ate behaviour and exploitation } \\
\text { of residents }\end{array}$ & $\begin{array}{l}\text { Educational } \\
\text { atmosphere }\end{array}$ & $\begin{array}{l}\text { The atmosphere at the depart- } \\
\text { ment, the occurrence of con- } \\
\text { flicts and the way in which peo- } \\
\text { ple treat each other }\end{array}$ \\
\hline Clarity of information & Autonomy & $\begin{array}{l}\text { Clarity of program information } \\
\text { provided }\end{array}$ & - & - \\
\hline $\begin{array}{l}\text { Quality of work } \\
\text { environment }\end{array}$ & $\begin{array}{l}\text { Accommodation and } \\
\text { catering facilities }\end{array}$ & $\begin{array}{l}\text { Quality of accommodation and } \\
\text { catering }\end{array}$ & - & - \\
\hline $\begin{array}{l}\text { Quality of formal } \\
\text { education }\end{array}$ & - & - & Formal education & $\begin{array}{l}\text { The quality and continuity of } \\
\text { planned educational moments } \\
\text { for residents }\end{array}$ \\
\hline $\begin{array}{l}\text { The balance between } \\
\text { work and knowledge/ } \\
\text { skills }\end{array}$ & - & - & $\begin{array}{l}\text { Work is adapted to } \\
\text { residents' competence }\end{array}$ & $\begin{array}{l}\text { The suitability of the tasks pro- } \\
\text { vided to the resident relatively } \\
\text { to the knowledge and skills base } \\
\text { of the resident }\end{array}$ \\
\hline Patient sign-out & - & - & Patient sign-out & $\begin{array}{l}\text { The degree in which patient } \\
\text { sign-outs are used as a moment } \\
\text { to educate residents }\end{array}$ \\
\hline
\end{tabular}




\section{Appendix A2}

Standardized and unstandardized coefficients with standard error, corrected item-total correlations, reliability coefficients, and summary statistics for the Spanish D-RECT

\begin{tabular}{|c|c|c|c|c|c|}
\hline Scale & Item & $\beta / \mathrm{B}(\mathrm{SE})^{*}$ & $\begin{array}{l}\text { Corrected item-total } \\
\text { correlation }\end{array}$ & $\begin{array}{l}\text { Cronbach's } \\
\text { alpha }\end{array}$ & Mean (SD) \\
\hline \multirow{5}{*}{$\begin{array}{l}\text { Educational } \\
\text { atmosphere }\end{array}$} & $\begin{array}{l}\text { Continuity of care is not affected by differences of opinion } \\
\text { between attendings. } \\
\text { (La continuidad de la atención no es afectada por las diferen- } \\
\text { cias de opinión de los especialistas) }\end{array}$ & $0.72 / 1.00(-)$ & 0.659 & 0.858 & $3.7(0.9)$ \\
\hline & $\begin{array}{l}\text { Differences of opinion between attendings about patient } \\
\text { management are discussed in such a manner that is instruc- } \\
\text { tive to others present. } \\
\text { (Las diferencias de opinión de los especialistas sobre el manejo } \\
\text { del paciente se discuten de una manera que es instructiva } \\
\text { para las demás personas presentes) }\end{array}$ & $\begin{array}{l}0.71 / 0.89 \\
(0.08)\end{array}$ & 0.619 & & \\
\hline & $\begin{array}{l}\text { Differences of opinion are not such that they have a negative } \\
\text { impact on the work climate. } \\
\text { (Las diferencias de opinión no tienen un efecto negativo en el } \\
\text { clima de trabajo) }\end{array}$ & $\begin{array}{l}0.87 / 1.26 \\
(0.10)\end{array}$ & 0.824 & & \\
\hline & $\begin{array}{l}\text { There is (are) NO attending physician(s) who have a nega- } \\
\text { tive impact on the educational climate. } \\
\text { (No hay ningún especialista que tenga un efecto negativo en el } \\
\text { clima educativo) }\end{array}$ & $\begin{array}{l}0.78 / 1.19 \\
(0.09)\end{array}$ & 0.712 & & \\
\hline & $\begin{array}{l}\text { My attendings treat me with respect. } \\
\text { (Los especialistas me tratan con respeto) }\end{array}$ & $\begin{array}{l}0.67 / 0.72 \\
(0.09)\end{array}$ & 0.574 & & \\
\hline \multirow{3}{*}{ Teamwork } & $\begin{array}{l}\text { Attendings, nursing staff, other allied health professionals } \\
\text { and residents work together as a team. } \\
\text { (Los especialistas, el personal de enfermería, el resto del per- } \\
\text { sonal de atención médica y los residentes trabajan en equipo) }\end{array}$ & $0.78 / 1.00(-)$ & 0.654 & 0.840 & $3.9(0.8)$ \\
\hline & $\begin{array}{l}\text { Nursing staff and other allied health professionals make a } \\
\text { positive contribution to my training. } \\
\text { (El personal de enfermería y el resto del personal de atención } \\
\text { médica contribuyen positivamente a mi entrenamiento) }\end{array}$ & $\begin{array}{l}0.87 / 1.02 \\
(0.06)\end{array}$ & 0.787 & & \\
\hline & $\begin{array}{l}\text { Nursing staff and other allied health professionals are willing } \\
\text { to reflect with me on the delivery of patient care. } \\
\text { (El personal de enfermería y resto del personal de atención } \\
\text { médica están dispuestos a reflexionar conmigo sobre como se } \\
\text { lleva a cabo el cuidado del paciente) }\end{array}$ & $\begin{array}{l}0.78 / 1.01 \\
(0.07)\end{array}$ & 0.682 & & \\
\hline \multirow{5}{*}{$\begin{array}{l}\text { Role of specialty } \\
\text { tutor }\end{array}$} & $\begin{array}{l}\text { The specialty tutor monitors the progress of my training. } \\
\text { (El coordinador de la especialización supervisa el progreso de } \\
\text { mi entrenamiento) }\end{array}$ & $0.82 / 1.00(-)$ & 0.744 & 0.880 & $3.8(0.8)$ \\
\hline & $\begin{array}{l}\text { The specialty tutor provides guidance to other attendings } \\
\text { when needed. } \\
\text { (El coordinador de la especialización orienta a otros especial- } \\
\text { istas cuando es necesario) }\end{array}$ & $\begin{array}{l}0.81 / 0.96 \\
(0.05)\end{array}$ & 0.737 & & \\
\hline & $\begin{array}{l}\text { The specialty tutor is actively involved in improving the } \\
\text { quality of education and training. } \\
\text { (El coordinador de la especialización participa activamente en } \\
\text { el mejoramiento de la calidad de la educación y el entrena- } \\
\text { miento) }\end{array}$ & $\begin{array}{l}0.79 / 0.87 \\
(0.06)\end{array}$ & 0.737 & & \\
\hline & $\begin{array}{l}\text { In this rotation evaluations are useful discussions about my } \\
\text { performance. } \\
\text { (En esta rotación, las evaluaciones son discusiones útiles sobre } \\
\text { mi desempeño) }\end{array}$ & $\begin{array}{l}0.75 / 0.83 \\
(0.07)\end{array}$ & 0.721 & & \\
\hline & $\begin{array}{l}\text { My plans for the future are part of the discussion. } \\
\text { (Mis planes de cara al futuro forman parte de la discusión) }\end{array}$ & $\begin{array}{l}0.61 / 0.74 \\
(0.08)\end{array}$ & 0.552 & & \\
\hline
\end{tabular}


During evaluations, input from several attendings is consid-

ered.

(Durante las evaluaciones se toman en cuenta los puntos de vista de varios especialistas)
$0.71 / 0.76$

(0.08)

My attendings take the initiative to evaluate my perfor-

$0.79 / 1.00(-)$

0.761

0.882 $3.7(0.8)$

mance.

(Los especialistas toman la iniciativa para evaluar mi desempeño)

My attendings take the initiative to evaluate difficult situations I have been involved in.

(Los especialistas toman la iniciativa para evaluar las situaciones difíciles que he tenido que enfrentar)

My attendings evaluate whether my performance in patient care is commensurate with my level of training

(Los especialistas evalúan si mi desempeño en la atención del

Coaching and assessment paciente es apropiado para mi nivel de entrenamiento)

My attendings occasionally observe me taking a history.

(Los especialistas ocasionalmente me observan realizando una historia clínica)

My attendings assess not only my medical expertise but also other skills such as teamwork, organization or professional behavior.

(Los especialistas evalúan no solo mis conocimientos médicos, sino también otras aptitudes como el trabajo en equipo, mi organización o mi conducta profesional)

My attendings give regular feedback on my strengths and weaknesses

(Los especialistas me retroalimentan frecuentemente sobre mis fortalezas y debilidades)

Residents are generally able to attend scheduled educational activities.

(Los residentes en general pueden asistir a las actividades educativas programadas)

Educational activities take place as scheduled. gramado)

Formal education Attendings contribute actively to the delivery of high-quality formal education.

(Los especialistas contribuyen activamente al logro de una educación formal de alta calidad)

Formal education and training activities are appropriate to my needs.

(La educación formal y las actividades de entrenamiento satisfacen mis necesidades)

Residents work well together. (Como grupo, los residentes se encargan de que se realice el

Within our group of residents, it is easy to find someone to cover or exchange a call.

(En nuestro grupo de residentes, es fácil encontrar a alguien con quien intercambiar o cubrir alguna actividad)

The work I am doing is commensurate with my level of experience.

Work is adapted to residents' competence
(El trabajo que hago es apropiado para mi nivel de experiencia)

The work I am doing suits my learning objectives at this stage of my training.
$0.80 / 0.83$

0.684 
It is possible to do follow up with patients.

$0.52 / 0.59$

0.446

(Es posible hacer seguimiento del estado de salud de los pa-

cientes)

When I need an attending, I can always contact one.

$0.85 / 1.00(-)$

0.751

0.864

$4.0(0.7)$

(Cuando necesito a un especialista, siempre puedo ponerme

en contacto con uno)

Accessibility of

When I need to consult an attending, they are readily availa-

$0.87 / 1.05$

0.794

supervisors

ble.

$(0.07)$

(Cuando necesito consultar algo con un especialista, lo

encuentro disponible rápidamente)

It is clear which attending supervises me.

$0.79 / 1.10$

0.698

(Está claro qué especialista me supervisa)

(0.09)

Sign-out is used as a teaching opportunity.

$0.84 / 1.00(-)$

0.782

0.878

$3.6(0.9)$

(La entrega de información del paciente durante el cambio de

turno (guardia) se utiliza como oportunidad de enseñanza)

Patient sign-out Attendings encourage residents to join in the discussion dur-

$0.93 / 1.12$

ing sign-out.

(0.07)

(Los especialistas fomentan que los residentes participen en la

discusión durante el cambio de turno (guardia)

${ }^{*} \beta=$ standardized coefficients; $\mathrm{B}=$ unstandardized coefficients; $\mathrm{SE}=$ standard error 


\section{Appendix A3}

Inter-scale correlations

\begin{tabular}{|c|c|c|c|c|c|c|c|c|c|}
\hline Domains & 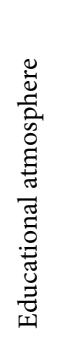 & 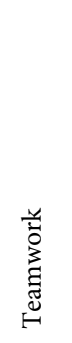 & 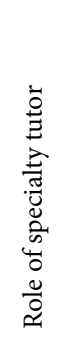 & 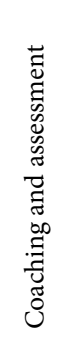 & 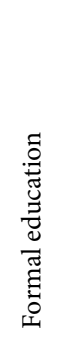 & 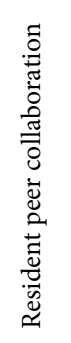 & 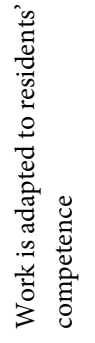 & 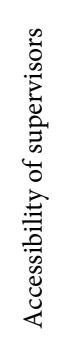 & 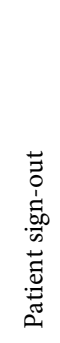 \\
\hline Educational atmosphere & 1 & 0.64 & 0.65 & 0.60 & 0.66 & 0.36 & 0.50 & 0.53 & 0.49 \\
\hline Teamwork & - & 1 & 0.58 & 0.54 & 0.51 & 0.53 & 0.56 & 0.54 & 0.36 \\
\hline Role of specialty tutor & - & - & 1 & 0.76 & 0.69 & 0.45 & 0.58 & 0.62 & 0.57 \\
\hline Coaching and assessment & - & - & - & 1 & 0.68 & 0.38 & 0.58 & 0.59 & 0.57 \\
\hline Formal education & - & - & - & - & 1 & 0.48 & 0.57 & 0.60 & 0.51 \\
\hline Resident peer collaboration & - & - & - & - & - & 1 & 0.53 & 0.52 & 0.21 \\
\hline Work is adapted to residents' competence & - & - & - & - & - & - & 1 & 0.65 & 0.57 \\
\hline Accessibility of supervisors & - & - & - & - & - & - & - & 1 & 0.46 \\
\hline Patient sign-out & - & - & - & - & - & - & - & - & 1 \\
\hline
\end{tabular}

